\title{
A C.N.E.R.: Uma Experiência em Administração Pública
}

JosÉ ARTUR RIos.

\begin{abstract}
A introdução de uma técnica ou idéia nova, em qualquer grupo humano, representa um desafio à inteligência. A tensão criada é ainda maior quando se trata de um serviço público, isto é, um conjunto de pessoas cujas atribuições e atividades se acham rìgidamente definidas e rigorosamente delimitadas dentro de um sistema inelástico de relações. Tôda administração representa um campo de atividades onde a mudança encontra barreiras de tôda ordem. muitas vêzes atribuídas a deficiências pessoais, mas que, na realidade, decorrem da posição dos indivíduos dentro do serviço, do cargo que ocupam, das relações formais que, durante muito tempo, se estabeleceram entre êsses cargos e do nicho que preenchem na hierarquia da repartição. $O$ statu quo burocrático representa sempre uma forma de adaptação à circunstância. Embora as deficiências pessoais existam, sobretudo num país em que a educação geral é tênue e o recrutamento para os quadros administrativos nem sempre obedece rigorosamente ao sistema do mérito, não constituem o maior obstáculo à renovação dos serviços. As lacunas, os hiatos na comunicação, as obstruçōes inerentes à própria organização, o ritmo vagaroso com que esta se adapta às modificações técnicas e sociais, a conformidade com que acompanha o crescimento vegetativo das estruturas econômicas e sociais, eis o que mais embaraça o trabalho do reformador.

Tudo isso foi sentido pelo grupo de técnicos que, em 1951, criaram a Campanha Nacional de Educação (C.N.E.R.) com a finalidade de introduzir no país as modernas técnicas da educação fundamental ou educação de base, que, a êsse tempo, aplicadas em vários países e áreas subdesenvolvidas, vinham sendo divulgadas pela U.N.E.S.C.O.. Por vários motivos, os aspectos administrativos dessa experiência merecem divulgação, tanto por suas vitórias, como por seus insucessos, para esclarecimento de todos que pretendam inovar alguma coisa numa estrutura burocrática.

Em 1951, a conjuntura política nacional levara a uma série de declarações demagógicas de "amparo" e "assistência" às populações rurais. Êsses slogans inócuos não se concretizavam, entretanto, em nenhum plano conjunto de ação governamental, ou numa coordenação de serviços e atividades que realmente viessem a constituir uma política rural. A tão falada Reforma Agrária não passava de um desejo platônico ou de um condimento demagógico. Os diversos serviços do Ministério da Educação e Saúde e do Ministério da Agricultura, as múltiplas Comissões diretamente ligadas à Presidência da
\end{abstract}


República, todos os ramos da administração, enfim, que se voltavam para as zonas rurais, continuavam a trabalhar da maneira mais dispersiva e rotineira. Quando muito, ao grito de alarma, que partia principalmente dos setores da produção, denunciando os níveis cada vez mais baixos de produtividade ve a crescente miséria que se alastrava em várias zonas do país, respondia-se com malabarismos fáceis na gangorra dos orçamentos, aumento de verbas a determinados serviços, sacrifício de outros, esforços que não se traduziam numa intensificação ou melhoria das técnicas de trabalho. Estabeleceu-se a competição pelas verbas. Contagiados pela demagogia ruralista, os diversos serviços se lançaram numa corrida acêsa cujo prêmio era uma fatia maior do orçamento.

Nesse impasse, se encontrava o Ministério da Educação e Saúde onde ume tradição que já vinha de longe não só divorciava a Educação da Saúde, como até, dentro de cada Departamento, compartimentava zelosamente as várias divisões do ensino. Faltava ao Ministério, principalmente, o órgão adequado para desenvolver no país um trabalho, a um tempo extenso e profundo, de educação das massas, quer rurais, quer urbanas. É verdade que já possuia, desde 1947, a Campanha de Educação de Adultos, mas esta se reduzira pràticamente, pela falta de imaginação dos seus mentores, a uma atividade epidérmica de simples alfabetização, restrita aos centros urbanos, conduzida e supervisionada numa base de puro controle burocrático e de distribuição de verbas a serviços estaduais.

Quando se pensou em levar os benefícios da educação fundamental, já consagrados em diversas áreas do mundo, às populações rurais brasileiras, o único ponto de apoio viável era, todavia, êsse serviço, ligado ao Departamento Nacional de Educação, e possuindo, no país, extensa rêde de cursos de alfabetização e centros de ensino profissional. Não havia outra alternativa, pois o país não dispunha, até essa data, de técnicos de educação de base, ou mesmo educadores de aduitos, ou sequer educadores de grupos especializados. As Faculdades de Filosofia não formavam educadores, no sentido amplo, dinâmico e anti-acadêmico da palavra, e, sim, professôres. Desenrolavam-se, porém, nos diversos Estados, várias iniciativas particulares, de leigos e religiosos, onde já se realizavam trabalhos muito próximos do que se chama educação fundamental. Alguns dêsses trabalhos tinham mesmo o nome de "missão rural", embora seus componentes nunca tivessem recebido nenhum treinamento especializado nem houvesse no trabalho a coordenação, a sistematização e o rigor de planejamento e técnicas indispensáveis a trabalhos dessa natureza. Essas tentativas se faziam à margem dos serviços oficiais que as ignoravam ou lhes davam um auxílio indiscriminado e acidental. Entregues a si próprias, fàcilmente descambavam para a filantropia e o paternalismo, à falta de uma diretriz educacional segura e de uma consciência clara dos seus propósitos. Às vêzes, recebiam auxílios estaduais ou municipais precários que não as habilitavam a produzir o máximo de rendimento e as expunham às oscilações e caprichos da política local.

A idéia da educação fundamental andava no ar. $\mathrm{O}$ que de melhor se fazia nesse sentido resultava da leitura dos trabalhos de divulgação da U.N.E.S.C.O. e da União Pan-Americana e da sua discussão em seminários e reuniões de 
técnicos. O exemplo do México, entre outros, divulgado pela U.N.E.S.C.O., sua experiência, em grande escala, da técnica da missão rural, representou para muitos um estímulo e uma provocação. A possibilidade de criação de um serviço social rural, de que já se falava nessa época, enfeixancio todos os serviços e manipulando polpudas verbas, encorajava trabalhos dessa natureza que poderiam tornar-se com o tempo, núcleos de irradiação e pontos de partida para essa organização, à qual faltavam exatamente princípios norteadores, - espécie de corpo disconforme em busca de uma alma.

Assim nasceu, por exemplo, a experiência de Itaperuna, cuja idéia brotou no Seminário Interamericano de Educação de Adultos, realizado em Petrópolis, em 1940, patrocinado pelo Govêrno Brasileiro, a U.N.E.S.C.O. e a União Pan-Americana. Nesse seminário, por proposta do Prof. LouREnço Frlho, ficou assentado que os Ministérios da Educação e da Agricultura organizariam um ensaio conjunto de educação de base. Como sói acontecer, a mudança de pessoas acarretou a subversão do plano original e a saída do Prof. LOURENço FILHo do Departamento Nacional de Educação fêz com que o Ministério se desinteressasse do empreendimento, passando essa experiência a ser coordenada pelo Serviço de Informação Agrícola do Ministério da Agricultura. Infelizmente, as condições em que decorreu, o método adotado, a escolha do local - o município de Itaperuna, no Estado do Rio de Janeiro, - e os quadros administrativos em que se desenrolava o trabalho não permitiam que servisse de demonstração para um serviço de tipo mais amplo.

Quando o Ministério da Educação resolveu, um pouco tàrdiamente, penetrar no terreno da educação de base, o problema foi colocado como se se tratasse de estender a Campanha de Educação de Adultos às zonas rurais. Partia-se de três pressupostos errôneos:

$1^{\circ}$ ) o problema da educação rural é um simples problema de alfabetização;

$2^{\circ}$ ) a educação rural emprega os mesmos métodos da educação urbana e

$3 .^{\circ}$ ) educar, no caso, é apenas ensinar.

A primeira tarefa que defrontaram os técnicos foi modificar essa mentalidade que dominava no Departamento Nacional de Educação. Antes de tudo, esclarecer os responsáveis sôbre o conceito de educação fundamental que pouco tinha a ver com alfabetização. Nascera exatamente da necessidade de aculturar populações infensas à alfabetização, ou melhor, que ainda não haviam encontrado no alfabeto o valor instrumental que possui para as populações urbanas ou semi-urbanizadas. A educação fundamental estava sendo utilizada para recuperar, em larga escala, populações de áreas subdesenvolvidas cujos problemas de carência, desnutrição, baixos níveis de vida, baixa produtividade, rotina de trabalho, alta mortalidade infantil constituem um pêso morto na organização social e econômica de vastas regióes do globo.

Outra idéia falsa era a identidade de meios entre a educação urbana e a rural, idéia que se baseava, muito lògicamente aliás, na fundamental identidade entre as populações rurais e urbanas. Nesse sentido, o esfôrço dos organizadores da Campanha foi trazer ao conhecimento dos administradores: 
o enorme cabedal de estudos do meio rural realizado por cientistas sociais brasileiros e estrangeiros, estudos que representavam uma segunda descoberta do Brasil e cujas conclusões permaneciam ignoradas e inaproveitadas pelos administradores como se não tivessem nenhuma aplicação prática. Ao contrário, os estudos de Lynn Smith, Pierson, Weibel, Wagley, Oberg, de um lado e as análises de Emilio Willems, Thales de Azevedo, Orlando VALVERDE e de tantos outros sociólogos, antropólogos e geógrafos documentavam a precariedade dos métodos acadêmicos e formais de transmissão de conhecimentos e apontavam para um tipo de educação que vencesse as resistências culturais de uma tradição já secular e esposasse a forma dessa cultura em vez de tentar sobrepor-se a seus padrões, sufocando-os.

Os métodos, portanto, tinham de sofrer profunda renovação e isso chocava a terceira convicção dos administradores segundo os quais, educar era ainda ensinar e, no caso, ensinar era alfabetizar. Tentou-se mostrar o ridículo dessa visão parcialíssima do problema educacional brasileiro, resíduo de uma era para a qual o letrado era o expoente e o ideal educacional por excelência. O objetivo era bem mais amplo: a renovação das técnicas de trabalho permitindo o acesso a níveis de vida mais consentâneos com a dignidade humana, a educação econômica que ampliasse ou melhorasse o equipamento profissional e aumentasse o rendimento do trabalho, o apêlo às energias latentes da solidariedade humana e a capacidade de liderança, o combate à apatia e a renovação das fontes de vida social pelo exemplo, pela iniciativa, pela emulação criadora. Era, na monolítica estrutura social que perdura nas zonas rurais brasileiras, o desbravamento de picadas que favorecessem a montée humaine, problema crucial de nosso tempo, e que o Brasil vive, à sua maneira, numa forma já superada em quase todos os países da civilização ocidental.

Fixados os princípios teóricos da Campanha, verificou-se que só muito lentamente podiam ser atingidos, ou mesmo encaminhados. Cautamente, enquanto se procedia ao esclarecimento dos administradores no Departamento Nacional de Educação, procedeu-se ao levantamento de tôdas as tentativas educacionais que já se faziam, entre nós, mais ou menos norteadas por êsses princípios e buscando realizar um ideal, às vêzes confuso, de educação fundamental. O ano de 1950 decorreu, quase todo, nessa tentativa. Era preciso conhecer minuciosamente cada serviço, cada entidade, cada campanha, pesar suas deficiências e recursos, sondar suas possibilidades futuras, sua dutilidade à orientação e à melhoria.

Foi assim que se fizeram interessantes "descobertas". No litoral de São Paulo, por exemplo, a ALA vinha trabalhando silenciosamente na formação de lideres e no levantamento dos níveis materiais e espirituais da população

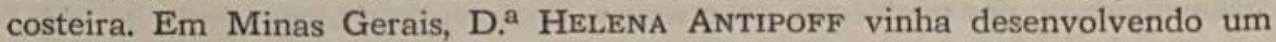
trabalho de aperfeiçoamento das professôras leigas do Estado e acariciando o projeto de um Instituto de Educação Rural. No Rio Grande do Norte, no Ceará, os Bispos se lançavam à formação ou ao aperfeiçoamento das professôras rurais leigas que suprissem o deficit de professôras normalistas, e ainda de auxiliares sociais, auxiliares de enfermagem e lideres catequistas. Essa primeira tomada de contato deu aos técnicos uma idéia das carências educa- 
cionais da massa rural e da maneira como estavam sendo supridas dentro e, principalmente, fora dos círculos oficiais. Inutil dizer que a grande maioria dessas experiências se desenrolava fora da órbita do Ministério da Educação que as ignorava por completo. E preciso dizer também que quase tôdas exigiam retificação, mas precisavam, acima de tudo, de coordenação, apoio financeiro e estímulo.

Esse trabalho preliminar, levado a efeito dentro do Departamento Nacio. nal de Educação, desenrolou-se com grandes dificuldades. Durante um ano, os técnicos não dispuseram de uma sala, nem sequer de uma mesa, e promoviam suas reuniões no gabinete do Diretor do Departamento, onde também recebiam as pessoas que os vinham procurar. Suas viagens constantes pelo interior causavam estranheza aos hábitos sedentários do funcionalismo ministerial que os considerava uma espécie de aves de arribação.

Esse primeiro núcleo de técnicos era integrado por três pessoas, duas das quais haviam sido requisitadas ao único serviço do Ministério da Agricultura que possuia o mínimo de experiência em difusão rural. Tratava-se da C.B.A.E.R., resultante de acôrdo firmado entre o Govêrno Brasileiro e o norte-americano para incentivar a educação rural. Enquanto a C.B.A.I. (Comissão Brasileiro-Americana de Ensino Industrial) prosperou, sua irmã gêmea feneceu. Decorridos alguns anos, o acôrdo foi rescindido e o espólio da C.B.A.E.R. foi, de certa forma, anexado à Superintendência do Ensino Agrícola, órgão do Ministério da Agricultura e passou a mover-se ùnicamente impulsionada pela iniciativa dos seus funcionários. A êsse tempo, com o equipamento audio-visual deixado pelos técnicos americanos, a C.B.A.E.R. montara uma unidade móvel constituída de um médico, um agrônomo, um técnico agrícola, um técnico de rádio e de cinema, os quais se deslocavam, periòdicamente, num furgão, procurando dar um conteúdo educacional às semanas ruralistas e às concentrações ocasionais de lavradores que se realizavam em áreas próximas ao Distrito Federal, no Estado do Rio e no Sul de Minas. Tratava-se de um trabalho epidérmico de difusão e propaganda, onde predominavam técnicas audio-visuais, projeções de filmes, demonstrações, palestras, etc. De qualquer forma, entretanto, havia nesse grupo certo espírito de equipe e realizavam com entusiasmo sua tarefa. O Ministério da Agricultura teria conseguido muito dêsses funcionários, se o tivesse desejado. Muito ao contrário, o serviço sofria constrangimentos de tôda ordem, cerceamento de verbas, mutilações, e raramente participava de qualquer planejamento de atividades gerais do Ministério.

Não havendo, na estrutura do Ministério da Educação, pessoal que tivesse essas características, pensou-se, inicialmente, em estabelecer acôrdo entre os dois serviços para aproveitar êsse pequeno grupo no novo tipo de trabalho. Promoveu-se para êsse fim reunião no D.N.E., com os chefes dos vários serviços interessados. Compareceram o Superintendente do Ensino Agrícola e o Diretor do S.I.A.. Em breve, verificou-se a impossibilidade de atingir êsse objetivo porque a natureza do trabalho năo era bem compreendida e o Superintendente encarava qualquer plano de acôrdo apenas como uma possibilidade de refôrço de suas verbas. A Superintendência funcionava numa base estática de auxílio e assistência às escolas de agricultura de tipo médio e tor- 
nava-se difícil entrosá-la num trabalho de natureza eminentemente dinâmica. Por outrc lado, as relações entre a Superintendência e o Serviço de Informação Agrícola eram mais de competição do que de colaboração. Acima de tudo, não se fazia a distinção clara entre educação - técnica, processo, forma - e agricultura (contexto, conteúdo, matéria). Os técnicos agrícolas não conseguiam entender que a crise do Fomento Agrícola residia, antes de tudo, na sua incapacidade em procurar o lavrador, em dinamizar-se, em utilizar, portanto, métodos e processos educacionais.

Verificando a impossibilidade imediata de um acôrdo que sòmente viria embaraçar o trabalho dos educadores, adiou-se êsse entendimento para momento mais oportuno e procurou-se contornar a dificuldade requisitando apenas dois componentes da C.B.A.E.R.. A requisição encontrou grandes embaraços. Embora êsses técnicos, naquele momento, não estivessem desempenhando nenhuma tarefa importante no Ministério, e, ao contrário, não conseguissem dar sequer o máximo de seu rendimento, a requisição foi encarada como uma tentativa de apropriação indébita e seu processamento assumiu, por vêzes, o aspecto de uma negociação de reféns. Conseguiu-se finalmente, que o Ministério cedesse um dos técnicos e "emprestasse" o outro.

Constituiu-se, dessa maneira, o núcleo inicial da futura Campanha: um sociólogo rural, um médico e um agrônomo. Restava estabelecer um plano de ação e aliciar outros elementos indispensáveis. Estabeleceram-se alguns princípios básicos. Partir do que já existia. Propor o financiamento, sob orientação, dos trabalhos que o merecessem. Melhorar seu pessoal. Dar-lhes supervisão adequada. Em segundo lugar: iniciar, desde logo, a formação de educadores de base e traçar as zonas preferenciais para os diferentes tipos de projetos. Essas zonas preferenciais foram discutidas e escolhidas com os geógrafos do Conselho Nacional de Geografia. Tomaram-se como critérios para essa escoIha:

$\left.1^{\circ}\right)$ a proximidade de centros urbanos;

$2 .^{\circ}$ ) áreas de pequena propriedade e de suficiente densidade demográfica; e

$3^{\circ}$ ) de rendimento econômico potencial onde o serviço encontrasse ponto de apoio e justificativa econômica. Tratava-se de ação educacional e não assistencial, e isto foi acentuado desde o comêço. Essa escolha representava, apenas, uma prioridade. Não excluiria as zonas menos favorecidas, apenas fazia das áreas escolhidas os pontos de inserção, onde os técnicos se adestrariam para zonas mais ásperas. Partia-se de princípio muito esquecido: no país, entre os técnicos e a população, conforme a área, a distância cultural varia consideràvelmente. Em certas zonas, o nível cultural cria ótimas condições para a ação direta do técnico. Em outras, seria mais proveitoso que a função de fermento social fôsse desempenhada por aquêles dentre os habitantes que revelassem capacidade de liderança e fôssem treinados para êsse fim. Todo o problema da educação de base consiste na criação de uma cadeia de inúmeros elos que, partindo da cúpula, da elite, assegure uma corrente contínua de comuniçação até a base que é a massa. O número reduzido de técnicos não chega para difundir seus ensinamentos num meio não só inculto 
mas que os repele. Por outro lado, começar numa área atrasada, onde as dificuldades são grandes e os problemas aparecem ainda maiores a principiantes, seria desencorajar os jovens técnicos que não teriam a oportunidade de ver, em pouco tempo, os resultados de seus esforços. Além disso, há, no país, muitas zonas de extraordinária receptividade ao trabalho educacional e que, no entanto, continuam em abandono.

Esse critério, não pôde, todavia, ser seguido à risca. De um lado, solaparam-no as investidas de certas secretarias ou departamentos de educação estaduais que logo viram no serviço nascente o caudal onde engrossariam o tênue filete das suas verbas. Surgiram de tôda parte, os mais inesperados pedidos de auxílio, amparados como de hábito, pelo indispensável esteio político. Houve pedidos do Acre, do Amazonas, de Mato Grosso; de clérigos e leigos; de civis e militares. Deputados e Senadores, solicitados por seus respectivos núcleos eleitorais, correram ao Departamento, brandindo telegramas, e pressionando a concessão de verbas.

Em vão, os técnicos procuraram se opor a essa dispersão de auxílios que criava insuperáveis problemas de supervisão. As etapas previstas seriam a formação dos educadores de base, e sua colocação em lugares de fácil supervisão para os três técnicos que teriam de ser, ao mesmo tempo, professôres e supervisores. A expansão das áreas de trabalho devia estar condicionada, antes de mais nada, ao número e à qualidade dêsses principiantes cuja formação e treinamento ainda não se começara. Essa dispersão, entretanto, se fazia sem a menor resistência da direção do Departamento Nacional de Educação e do próprio Gabinete do Ministro, dóceis, como sempre, às solicitações de caráter político ou pessoal.

Em fins de 1951, constituiu-se, mal e mal, o núcleo de um serviço. Deuse-lhe o mínimo de condições materiais para o início do planejamento. Obtida a inserção de verbas no orçamento do Ministério, pôde-se, afinal, planejar certas atividades. Chamou-se à nova entidade Campanha Nacional de Educação Rural (C.N.E.R.), embora a expressão Educação Rural não traduzisse bem seu sentido e suas finalidades. Essa denominação, entretanto, foi adotada para distinguir o novo serviço da Campanha de Educação de Aduitos que, teòricamente, operava em zonas urbanas. A C.N.E.R. estava subordinada ao Diretor do Departamento Nacional de Educação e era dirigida por um Coordenador. Constituiam-na quatro setores:

$10^{\circ}$ ) Estudos e pesquisas;

$\left.2 .^{\circ}\right)$ Treinamento;

$\left.3 .^{\circ}\right)$ Missões Rurais e

4. ${ }^{\circ}$ ) Divulgação.

O primeiro a cargo de um geśgrafo, especialista em geografia agrária, dispondo de pesquisadores sociais, teria a incumbência de fazer o levantamento prévio das áreas do ponto de vista dos critérios básicos de escolha e de elaborar um conjunto de recomentações a serem seguidas pela equipe quando iniciasse seu trabalho. Essas recomendações diziam respeito ao tipo de solo, às técnicas agrícolas adotadas e a melhorar, às relações entre a sede urbana e a zona rural, às instituiçōes e entidades mais importantes, ao tipo 
de liderança existente na área e aos meios mais importantes de comunicação a serem utilizados pela equipe. O Setor de Treinamento ficou responsável por todos os tipos de pessoal e pela sua formação. Organizava os cursos de educação de base, onde se preparavam os técnicos das missões rurais, os supervisores, e ainda os funcionários de outras entidades, públicas ou privadas, federais ou estaduais que, em acôrdo com a Campanha, desejavam beneficiar-se dos seus serviços. Promovia ainda cursos para professôres municipais ou para qualquer outro tipo de líder a fim de levantar-lhes o nível profissional e fazer com que se tornassem outros tantos instrumentos de penetração dos ideais e das técnicas da Campanha.

O Setor de Missões Rurais estava encarregado de assistir e supervisionar a atividade das Missões. Adotou-se, como norma de trabalho, nas missōes da Campanha, só admitir técnicos que houvessem passado por um dos cursos. Nos serviços em regime de acôrdo, criou-se a mesma obrigatoriedade, tolerando-se que nêles permanecessem leigos apenas enquanto a capacidade dos cursos a isso os obrigasse. Assim, o Setor de Missões e o de Treinamento constituiam as peças mais importantes do Serviço e, por seu intermédio, planejava-se e executava-se todo trabalho de educação de base. Por êsse motivo, era imperativo que funcionassem em estreita colaboração. O Setor de Treinamento recebia os pedidos de técnicos do Setor de Missões e êste transmitia ao primeiro as deficiências dos cursos tais como eram sentidas no campo. Por se tratar de uma grande experiência educacional, procurou-se libertar a organização de qualquer esquema rígido que impedisse essa constante adapiação e readaptação.

Finalmente, o Setor de Divulgação planejava e executava o preparo de material educativo. Não se tratava de um pequeno Dip tão na moda, nessı tempo, em cada serviço e até indispensável na luta pela verba e na com. petição pelcs favores ministeriais. Elaborava o material a ser utilizado nos cursos (é preciso lembrar que nada existia sôbre o assunto em língua portuguêsa), traduzia e divulgava material estrangeiro de relevância, promovia cursos e conferências em assuntos educacionais, preparava e reunia material audio-visual, posteriormente utilizado nos cursos de treinamento e nas missões rurais.

Quanto à administração, pròpriamente dita, procurou-se restringí-la ao mínimo, simplificando seu mecanismo. Um chefe de escritório e um contador, com dois auxiliares, eram os encarregados de controlar as despesas, orientar o pessoal dos acôrdos, fazer a necessária tomada de contas e fiscalizar a aplicação de verbas, assessorando diretamente o Coordenador.

A atuação da C.N.E.R. nos Estados se exercia através de uma rêde flexível de acôrdos e projetos. Evitava-se com êsse sistema a centralização esterilizante oprimindo iniciativas que já haviam nobremente conquistado seu lugar ao sol e que nenhum serviço federal tinha o direito de encampar ou asfixiar. Tratava-se de ajudar êsses pioneiros a caminhar para a maturidade e para a autonomia, orientando-os para financiá-los, dando-lhes recursos e, ao mesmo tempo, ensinando-os a aproveitá-los ao máximo. Nem o financiamento puro e simples, que resultaria em esperdício e dispersão de verbas, nem a orienta- 
ção distante e teórica de pouco proveito sem o financiamento. No acôrdo firmado com a entidade ou o serviço, procurava-se sempre fazer com que a outra parte contratante desse sua contribuição, por mínima que fôsse. Dentro de um acôrdo, as verbas eram distribuídas conforme os projetos a desenvolver, o que facilitava sua fiscalização e contrôle. Dentro do acôrdo geral com o Estado A, por exemplo, podia haver um ou mais projetos, - centro de treinamento, missões rurais, cursos para líderes, etc., - cada um com sua verba própria. À testa de cada acôrdo havia um Executor, designado, em comum, pela C.N.E.R. e pela outra entidade. À frente de cada projeto, havia um diretor ou responsável. A função dos Executores era quase inteiramente administrativa, mas procurava-se familiarizá-los com os processos educacionais e os objetivos da C.N.E.R., a fim de que, no mais rápido prazo possível, pudessem caminhar por si mesmos, tornando-se outros tantos focos de irradiação da Campanha. Nesse sentido, promoviam-se reuniōes na sede, no Rio de Janeiro, ou nos Estados, estimulavam-se visitas de Executores a locais onde houvesse projetos em fase adiantada de execução e favoreciam-se entendimentos multilaterais visando projetos estaduais ou regionais. O sentido da Campanha, inseparável de sua missão educacional, era a descentralização e se tal não foi possível, desde o primeiro dia, dado o despreparo e o desconhecimento do trabalho, nunca se perdeu de vista êsse objetivo.

Se os Executores eram, antes de tudo, administradores, os diretores de projetos tinham de ser, em primeiro lugar, técnicos, educadores. Uma das finalidades dos cursos de treinamento era formar pessoas que, em número cada vez maior, depois de passar por um período de aprendizagem no campo e dar as necessárias provas de maturidade e discernimento, pudessem vir a assumir essas posições de comando na estrutura da Campanha. Os executores iam buscar, nos centros de treinamento seus auxiliares mais eficientes. Interessavam-se, por isso, em escolher nos seus Estados, nas suas organizações, os melhores elementos e os enviavam aos cursos da C.N.E.R. para receberem êsse treinamento básico.

A primeira experiência de um curso regular de educação fundamental no Brasil data de 5 de março de 1952 . A história dessa primeira experiência iniciada e realizada numa fase em que a Campanha não tinha pròpriamente autonomia administrativa nem financeira esclarece, melhor que quaisquer divagações teóricas, as dificuldades enfrentadas. A 16 de julho de 1951 firmara-se o acôrdo entre o Ministério da Educação e Saúde e o Govêrno do Estado de São Paulo para desenvolvimento da Campanha de Educação de Adultos e Adolescentes nas zonas rurais do Estado e para a criação e manutençăo de centros de iniciação artesanal e profissional. Êsse acôrdo, feito nos moldes dos convênios da Campanha de Educação de Adultos, trazia, em seu bôjo, diversos êrros técnicos. Restringia a atuação da Campanha às zonas rurais, sem as definir e, além disso, subordinava a contribuição do Govêrno Federal ao número de centros de iniciação profissional a serem fundados no Estado. Tampouco se sabia exatamente o que fôsse centro de iniciação profissional, aos quais se atribuía determinada verba. Em vez de condicionar a verba ao tipo de trabalho, fazia-se o inverso. Os Estados, sempre necessitados de dinheiro 
aproveitavam-se; se precisavam de dois milhões, pediam o correspondente número de centros. Verifica-se, por aí, que os convênios não passavam para os Estados de uma forma engenhosa e cômoda de drenar verbas federais para suas necessidades. No caso da Campanha, para que o novo acôrdo se adaptasse às novas finalidades, tornou-se necessário falar em centros sociais rurais, atribuindo a cada um determinada importância. Essa impostura viciou todo o convênio.

O acôrdo não mencionava nem as missões rurais nem os centros de treinamento de líderes de base, objetivos específicos da Campanha, expressamente definidos nos documentos oficiais que the deram origem. Contrariando normas técnicas, a idéia assistencial primava a de educação. O centro social rural que, conforme o caso, poderia ou não surgir do trabalho das missões, aparecia em primeiro plano, como uma organização complexa e ao mesmo tempo estática, que oferecia às populaçōes circunvizinhas tôda ordem de serviços, desde a assistência econômica até a recreativa. Decalcado sôbre os convênios que visavam à alfabetização e à iniciação profissional, o acôrdo estabelecia que o Govêrno Federal concorreria com somas nunca inferiores a dois têrços do que despendia o Govêrno Estadual em serviços congêneres. Ora, o Govêrno Estadual nunca possuíra, até aquela data, nada que se parecesse aos centros sociais rurais, de modo que o cálculo da contribuição tanto federal, como estadual, era inteiramente arbitrário. Da parte do Estado, aliás, essa contribuição jamais foi prestada em espécie e tudo correu como se todos esperassem que isso acontecesse.

Previa ainda o documento que os centros seriam instalados em dez cidades, expressamente mencionadas, embora não esclarecesse a razão dessa escolha. Mas, se os centros eram rurais como podiam ser colocados em cidades? Finalmente, o acôrdo entregava a responsabilidade técnica do plano à Secretaria da Educação do Estado de São Paulo que, evidentemente, não se achava aparelhada para êsse fim. Se o estivesse, não haveria motivo para o acôrco. onde a única contribuição do Ministério da Educação e Saúde era de ordem financeira.

Daí por diante, acumulam-se os equívocos. O Ministério designou un Delegado Técnico em São Paulo para acompanhar a execução do convênio, sob a orientação do Coordenador da Campanha. Evidenciou-se, imediatamente, a necessidade de uma articulação permanente entre as Secretarias de Educação, Saúde e Agricultura, tôdas diretamente interessadas no plano que se pretendia desenvolver. O Govêrno do Estado baixou decreto criando uma Comissão Executiva do acôrdo, integrada por funcionários daquelas Secretarias a fim de inaugurar no Estado a "Campanha de Educação Rural" (sic). Era a primeira vez que se falava expressamente em educação rural, finalidade implícita do convênio, mas que não aparecera em nenhuma de suas cláusulas.

Baseando-se no texto do acôrdo, o Governador designava o Secretário da Educação como responsável direto pela sua execução e incluía na Comissão o representante da Campanha de Educação de Adultos no Estado. Procurou-se imprimir aos trabalhos da Comissão o espírito que ditara o convênio, 
mas logo surgiram dois tipos de obstáculos. Foi difícil transmitir aos membros da Comissão a idéia de que se tratava de iniciativa inteiramente nova, que precisava ser bem compreendida. Cada membro interpretava a idéia de educação fundamental à luz de suas experiências, que nem sempre coincidiam com o que se pretendia fazer. A Secretaria de Educação falava em "educação rural" dentro dos padrões formais de ensino, em têrmos de escola e professôra. A Secretaria da Saúde entendia o plano como a simples conti. nuação de trabalhos de saúde pública em áreas do Estado onde se procurava integrar o programa sanitário nos diversos setores da vida local. Por mais interessantes que fôssem essas experiências e algumas, de fato, representavam considerável avanço sôbre a rotina do serviço, não configuravam exatamente o que se programava como atividade de educação de base. A Secretaria de Agricultura imaginava o trabalho como um desdobramento do que já vinhn fazendo em matéria de extensão agrícola, num esfôrço de superação do que havia de estático e precário na organização das "Casas da Lavoura". Finalmente, o representante da Campanha de Educação de Adultos não conseguia sair da bitola da alfabetização e não compreendia o sentido da Campanha. O formalismo burocrático não tardou a entrar em cena emperrando a dinâmica do trabalho e criando entre as várias Secretarias e o Ministério a inevitável cortina de papel.

Esperava-se que êsses equívocos se dissipassem com a realização do primeiro curso de treinamento de educadores de base e procurou-se acelerar os trabalhos ao máximo. Coube à C.N.E.R. imprimir a orientação geral dos cursos, fornecer os professôres das matérias básicas; e às Secretarias selecionar os técnicos que iriam integrar o corpo discente e docente, providenciar o local de instalação e tomar tôdas as providências necessárias ao seu equipamento. Previu-se que a Secretaria de Educação enviaria professôres, principalmente os que tivessem alguma experiência de educação de adultos no meio rural. À Secretaria de Agricultura caberia enviar agrônomos com experiência em extensão. A Secretaria de Saúde deveria escolher médicos, enfermeiras e educadores sanitários com alguma prática de saúde pública e, ainda, assistentes sociais. Os programas deviam ser simples, objetivos, adequados à natureza intensiva e complementar do curso, cuja finalidade era dar a conhecer êsses técnicos uns aos outros e revelar-lhes o que havia de comum em seu trabalho, transmitindo-lhes o espírito de equipe. $\mathrm{E}$, ainda demonstrar-lhes pràticamente as possibilidades da pedagogia social e o enriquecimento que decorreria de sua aplicação sistemática em cada um dos campos de atividade ali representados.

Explicou-se à Comissão que a principal finalidade do curso era preparar elementos para as missões rurais que iriam trabalhar no Estado; dar-lhes uma consciência educacional e, acima de tudo, um espírito. O curso devia ser, a um tempo, teórico e prático. Devia incluir, como matérias básicas, sociologia rural, psicologia educacional e pedagogia, educação sanitária e extensão agrícola; mais as técnicas fundamentais da educação de grupos e de comunidade e da educação audio-visual. A parte teórica devia ser seguida pela aplicação prática, no campo, desde o primeiro momento, numa tarefa concreta de educação a realizar-se em área a ser escolhida. A capacidade máxima do curso 
devia ser de trinta alunos em regime de internato, combinando-se trabalho intensivo e recreação adequada.

No momento da elaboração dêsses programas, e da escolha do corpo docente e discente, começaram a fazer-se sentir os efeitos da desorientação que presidira à redação do acôrdo. Reduzido ao mero papel de assistente técnico, o representante do Ministério teve de desenvolver esforços para evitar que o trabalho malograsse por completo. Os programas elaborados pelas Secretarias eram, na sua maioria, inviáveis para a duração do curso e brigavam com as finalidades propostas. Eram vagos, inadequados, dispersivos. Sobrecarregados de teoria, envolviam noções que, normalmente, são ministradas em cursos universitários ou post-universitários de longa duração.

Os entendimentos para a escolha do local alongaram-se, diluidos em reuniões estéreis e debates acadêmicos. Esse passo inicial era tão importante para o Ministério como para o Estado. O curso visava criar o núcleo inicial de onde, mais tarde, se poderia partir para um centro regional, nacional ou mesmo sul-americano de educação de base. Pelos seus recursos humanos e financeiros, pela facilidade de comunicações, pela proximidade dos grandes centros culturais do país e, principalmente, pela variedade de zonas agrícolas, São Paulo era o laboratório natural que reunia tôdas as condiçōes necessárias a essa experiência.

Finalmente, escolheu-se o local. Seria a Escola Agrícola Industrial Carolino da Mota e Silva, pertencente à Secretaria da Educação, situada no município de Pinhal. A Escola dispunha de vastas instalações e se achava no centro de uma região caracterizada por diversos tipos de propriedade rural, o que vinha satisfazer às necessidades do curso. Recomendava-a, ainda, a proximidade de São Paulo, a três horas de automóvel, por uma estrada bastante boa. A duas horas de percurso encontrava-se a colônia holandesa de Holambra, perto de Campinas, admirável centro de demonstração de técnicas agrícolas e de conservação do solo.

Adiado por três vêzes, inaugurou-se finalmente o curso a 5 de março de 1952. Dirigia-o o Delegado da Campanha de Educação de Adultos em São Paulo. O Departamento Nacional de Educação foi avisado apenas com dois dias de antecedência, e enviou os técnicos da Campanha. Ali chegando, verificaram que, além do habitual noticiário à imprensa, nenhuma providência concreta fôra tomada para que o curso tivesse o resultado planejado. Não havia nenhum material didático. Nem um mimeógrafo. Não se cogitara de contratar pessoal de secretaria, nem mesmo datilógrafas. As apostilas tiveram de ser datilografadas pelas próprias alunas e utilizou-se o mimeógrafo da escola que não dava o rendimento necessário, além de estar constantemente bloqueado por material publicitário de nenhum valor que se destinava à imprensa local. Quanto à parte recreativa, ninguém havia pensado nisso. Constituía, no entanto, problema importante num curso onde moças e rapazes deviam conviver, em regime de internato, durante trinta dias.

Mais grave, ainda, era o problema do transporte. Dados os afazeres que prendiam os professôres a São Paulo e ao Rio, foi necessário programar as cadeiras de semana a semana. Para isso era necessário assegurar comunicações rápidas com São Paulo. Além disso, o trabalho de treinamento prático que 
ocupava tôda a parte da manhã exigia condução para os alunos que partiam cedo da Escola rumo às sedes de distrito, onde realizavam um programa educativo prèviamente discutido e planejado. Aqui se situa o incidente das "peruas" que nos parece bastante expressivo.

Assim que o acôrdo com o Ministério da Educação foi assinado e noticiado nos' jornais paulistas, a Secretaria de Educação da Prefeitura de São Paulo resolveu doar à Comissão Executiva, três "peruas" marca "Nash", equipadas com rádio, projetor cinematográfico e biblioteca circulante. Esses veiculos foram solenemente ofertados à Campanha, em cerimônia pública, no Pátio do Colégio, com a presença do Diretor do Departamento Nacional de Educação, Secretário de Educação do Estado e demais autoridades. De acôrdo com o Regulamento elaborado pela Comissão, êsses veículos só podiam ser utilizados com a autorização do seu Presidente, o Secretário da Educação. Por êsse motivo, foram recolhidos à garage da Secretaria. Em breve, porém, começaram a chegar ao Ministério notícias de que estariam sendo usados como veículos particulares, sendo vistos pela cidade em horas e lugares inteiramente estranhos a sua finalidade. Ao participarem do Congresso de Educação Rural, em São Carlos, os técnicos do Ministério puderam verificar que as "peruas", entregues a irresponsáveis, eram usadas até para carregar objetos de uso pessoal dos congressistas. Deram ciência dêsses fatos à Comissão, pedindo-lhe providências para sustar abusos que ameaçavam desmoralizar a Campanha perante a opinião pública paulista. A Comissão, entretanto, declarou-se impotente para modificar êsse estado de coisas. Buscou-se, então, um entendimento direto com o Secretário de Educaçâo e êste assegurou ao coordenador da C.N.E.R. que já havia tomado as medidas necessárias para recoIher as duas "peruas" à garage da Secretaria. "Mas são três, Excelência". "Sim, mas uma fica para meu uso pessoal, porque estou sem carro".

Assim, quando o curso teve início, os veículos, reduzidos a dois, já se encontravam em péssimas condiçốes de conservação, e só faziam rápidas e espaçadas visitas ao centro de treinamento de Pinhal, logo voltando a São Paulo. Essa dificuldade foi parcialmente superada graças a alguns alunos que puseram seus carros particulares à disposição dos colegas, e com o aluguel de carros de praça. O custo do treinamento aumentou bastante com essa despesa inesperada.

A medida que o curso progredia e se conheciam melhor os alunos, tornou-se evidente que o critério de seleção fôra dos mais duvidosos. A grande maioria, pela idade, pelas responsabilidades já assumidas, ou pela situação que ocupavam em suas localidades de origem, jamais poderiam dedicar-se ao trabalho das missões rurais que exigia técnicos moços e empreendedores, sem compromissos, de preferência solteiros que não tivessem sido viciados pela rotina burocrática. $\mathrm{O}$ exame das fichas dos alunos revelava pessoas de mais de quarenta anos, cujas aspirações não se harmonizavam com os objetivos e possibilidades da Campanha. Dos elementos reunidos em Pinhal, só os agrônomos e assistentes sociais reuniam condiçōes para ingressar no trabalho das missões. Dos médicos, educadoras e enfermeiras, raro era aquêle que poderia abandonar seus interêsses e conformar-se ao tipo de vencimento que a Campanha podia pagar. Quanto às professoras, a maioria havia sido comissionada segundo 
um criterio de gritante protecionismo. Eram quase tôdas moças da cidade. sem nenhuma experiência do meio rural, embora muitas tivessem revelado, no decorrer do curso, qualidades de inteligência e trabalho. $\mathrm{O}$ mais estranho é que tinham sido comissionadas por um ano, embora, depois do curso, ninguém soubesse que destino deviam tomar.

Os projetores cinematográficos jamais apareceram. Um dos alunos ofertou o seu e a Campanha enviou um equipamento audio-visual completo para treinamento dos alunos. Houve momentos em que se esteve muito perto do cáos. A sucessão das cadeiras foi mal coordenada e, por vêzes, os alunos passaram vários dias sem aula de qualquer espécie. Um dos programas foi ministrado por vários professôres que chegavam a Pinhal e regressavam no mesmo dia sem entrarem em contacto uns com os outros. Não houve nenhuma reunião preparatória e quando as aulas se mostravam adequadas às finalidades projetadas era puro acaso.

Apesar de tudo, êsse curso representou um marco. Os testes finais revelaram alto índice de aproveitamento. Os alunos sentiram que estavam no limiar de algo novo e que haviam enriquecido a visão de seu campo profissional, ampliando suas possibilidades de ação. Mesmo aqueles que não pretendiam, nunca haviam pretendido, participar do trabalho das missões, compreenderam a importância da educação fundamental e de suas técnicas em saúde pública, agricultura e serviço social. Esse resultado foi devido, antes de mais nada, aos próprios alunos, cujo entusiasmo salvou o curso da desintegração a que o teria levado fatalmente a inépcia administrativa. Compreenderam que se tratava de uma experiência e que eram êles os principais responsáveis pelo seu sucesso ou fracasso. Por outro lado, a diretoria da Escola não poupou esforços para oferecer a alunos e professôres o mínimo de condições materiais de estudo, alimentação e repouso que garantiram o sucesso da experiência.

Dessa primeira turma, a C.N.E.R. escolheu alguns elementos que vieram reforçar o núcleo já constituído em São Paulo. Tudo indicava que não era possível continuar com a mesma organização administrativa. A Comissão Executiva era um mecanismo difícil na colaboração com o Estado. Optou-se por um executor que passou a ser o responsável por tôda a coordenação dos serviços estaduais, mediante autorização expressa do Governador. A C.N.E.R. fornecia-lhe diretamente as verbas das quais prestava contas. Incumbia-se de reunir os elementos materiais e humanos necessários ao treinamento e mais trabalhos da Campanha no Estado. Quanto à seleção e organização técnica do curso, escolha de professôres e organização dos programas, a própria Campanha teve de assumir essa responsabilidade para evitar os dissabores da primeira experiência.

No Estado de São Paulo, após êsse primeiro curso, só se pôde constituir uma missão rural que passou a funcionar no município de Pinhal, artiçulada com o centro de treinamento que se esboçava. Serviria de demonstração das técnicas da educação de base aos alunos dos cursos subseqüentes. Seus elementos funcionaram como monitores nesses cursos e passaram, depois, a assumir funções de ensino e supervisão que até hoje ocupam.

Os resultados da mudança administrativa foram claramente sentidos nos cursos que, dai por diante, passaram a ser realizados em Pinhal. O regime do 
Executor facilitou os contatos da C.N.E.R. com o Estado, o contrôle das verbas e-a assistência técnica. A direção do curso foi entregue a um funcionário da própria Escola que se desincumbiu da tarefa com absoluta probidade e zêlo. Por outro lado, a dissolução da Comissão Executiva não se fez pacificamente. Houve as habituais censuras e protestos, seguidos de um retraimento dos elementos excluídos e de ataques pela imprensa contra a C.N.E.R.

Não se pode dizer, entretanto, que o regime do Executor, no Estado de São Paulo, tenha atingido o ideal. A necessidade de se escolher um funcionário de uma das três Secretarias interessadas no programa criava dificuldades de tôda ordem. $O$ fato de se tratar de cargo remunerado, acendia a cobiça de todos os marginais do funcionalismo estadual e acirrava a política mesquinha das Secretarias. Nem sempre o designado se achava à altura du cargo. Candidataram-se professôras aposentadas e até declamadoras. Em certa época, a pessoa designada pelo Governador, por indicação de um dos Secretários, tinha nas costas um processo crime e andava foragida da polícia. O Estado vivia, em sua administração, um momento crítico. A crise de autoridade instaurada por anteriores governos e a mediocridade das chefias contras. tavam com a pletora de recursos e a qualidade dos moços e moças que procuravam, em número cada vez maior, a C.N.E.R., não apenas como uma possibilidade de emprêgo, mas como uma vocação e um sentido de vida.

O segundo curso, realizado em Pinhal, consolidou definitivamente a Campanha. Nêle se formaram os técnicos que passaram a atuar nas primeiras missōes rurais do Rio Grande do Sul, Paraná, Sul de Minas e Estado do Rio. Nesse mesmo ano, com o fim de iniciar o trabalho em grande escola no Nordeste instalou-se outro centro de treinamento na Escola Agronômica de Cruz das Almas, na Bahia. Aí se formaram os técnicos que iniciaram o trabalho nos Estados da Bahia, Alagoas, Ceará e Rio Grande do Norte. As clificuldades surgidas nesse curso eram de natureza bem diversa. O sistema do Executor funcionou admiràvelmente. $\mathrm{A}$ escolha do Estado da Bahia recaiu em pessoa que possuía, em alto grau, qualidades de iniciativa, eficiência. prestígio e habilidade no trato pessoal. No entanto, as condições materiais punham à prova a dedicação dos alunos. A Escola de Agronomia, à míngua de verbas, sem dinheiro para pagar os próprios professôres, apesar da boa vontade de sua direção, pouco podia oferecer à Campanha que teve de mobilizar todos os seus recursos para atender ao treinamento. De qualquer maneira, porém, sentida a necessidade e demonstrada a eficácia das primeiras missões, caminhava-se no sentido de fixar, tanto em Pinhal como em Cruz das Almas, dois centros regionais de treinamento, preparando em ritmo regular, turmas sucessivas de educadores dos mais diversos níveis, não só para as missōes, como para todos os tipos de atividade educacional no meio rural. $O$ primeiro curso de Pinhal formou 25 alunos. O segundo, 47. O terceiro (primeiro da Bahia), 43. O quarto, ainda em Pinhal, 37. O quinto, em Florestal, Minas Gerais, 35. O sexto, também em Florestal, 34. O sétimo, na Escola Rural de Osório, Rio Grande do Sul, 27. O oitavo, em Piraçununga, São Paulo, 44. O nono em Colatina, Espírito Santo, onde recentemente se fixou o centro de treinamento, 31 alunos. De 1952 a 1954, a C.N.E.R. realizou nove cursos, formando um total de 330 alunos, entre agrônomos, assistentes sociais, dentistas, educadoras familiares, educadoras sanitárias, enfermeiras, médicos professôras normalistas, 
sacerdotes, técnicos agrícolas e vários ouvintes. (1) Fixaram-se as matérias básicas e o conteúdo de cada programa foi reduzido ao essencial. Se foi perniciosa à Campanha a instabilidade da localização dos centros de treinamento, que flutuou ao sabor dos interêsses e apêgos políticos dos responsáveis, não é menos verdade que o entusiasmo e a pertinácia dos jovens que integraram o núcleo inicial realizaram uma experiência respeitável.

Em 1955, a C.N.E.R. possuía quatro missões funcionando no Estado da Bahia, uma em Alagoas, duas no Ceará, uma no Maranhão, uma em Minas Gerais, uma na Paraíba, uma no Estado do Rio, duas no Rio Grande do Norte, onze no Rio Grande do Sul, uma em São Paulo; possuia centros de treinamento de professôres rurais em Alagoas, Bahia, Ceará, Maranhão, Minas Gerais, Pernambuco, Rio Grande do Norte, e em São Paulo. Em vários Estados formava líderes cooperativistas e mantinha centros sociais. Êsse resultado é tanto mais apreciável quando se sabe que as dificuldades de tôda ordem. não desapareceram. E claro que a localização de grande parte dessas missões é discutível. Discutibilíssimo, por exemplo, o número desproporcionado de missões na fronteira do Rio Grande do Sul, em região inteiramente contraindicada, servindo flagrantes interesses eleitoralistas. $\mathrm{E}$ ainda duvidoso que a C.N.E.R. tenha atingido a maturidade suficiente para manter um único centro de educadores de base, em Colatina, apressada e prematuramente rotulado de centro nacional de educação de base. $\mathrm{O}$ custo médio anual de uma missão - $\operatorname{Cr} \$ 500.000,00$ - seria o suficiente para que se ponderasse' mais detidamente sua localização. $\mathrm{E}$ a verba do centro naciônal de educação de base, $\mathrm{Cr} \$ 3.500 .000,00$ é de molde a inspirar cuidados a todos que desconfiam e temem em iniciativas novas o gigantismo, geralmente acompanhado de microcefalia. A proliferação de centros sociais rurais em localidades onde sua criação não foi precedida de um seguro trabalho de preparação de líderes ou em áreas onde nada mais representam que um quisto cultural sem nenhuma relação viva com as instituições já existentes, parece trazer à C.N.E.R. o perigo de um resvalo insensível no paternalismo contra o qual tentou vigorosamente reagir na sua primeira fase. Já a preocupação de melhorar o nível do professorado rural representa trabalho sólido e altamente remunerador. A formação e a orientação de líderes, em geral, representa um dos caminhos mais fáceis, práticos, rápidos e econômicos, de acelerar as desejadas mudanças no sistema de vida e trabalho das populações do nosso interior. Se êsse trabalho se estender às populações menos favorecidas das cidades, como já se vem fazendo em , Salvador, sem a preocupação esterilizante do "ruralismo", a Campanha terá realizado um grande passo no sentido de integrar todos os esforços que se vêm desenvolvendo no Brasil pela educação das massas.

Parece, todavia, que certos objetivos iniciais foram esquecidos. Partiu-se de uma idéia sadia e democrática de descentralização progressiva. A participação da Campanha seria cada vez menor nos Estados que pudessem financiar o trabalho, reservando-se maior atuação naqueles que menos dispusessem de recursos. A própria orientação técnica deveria tender, no sul do Brasil, a uma simples supervisão dos serviços, a uma ação mais catalizadora. Dada a diyer-

(1) Dacios oficiais da C.N.E.R. 
sidade de áreas, populações, recursos e problemas, os centros regionais ou estaduais de treinamento deveriam incumbir-se da formação do pessoal técnico e responderiam melhor a sua finalidade, de menor custo e maior rendimento, pelo menos, que um grande centro nacional, cuja localização nunca será satisfatória. Sua existência só se justificaria para a formação de supervisores, de técnicos de alto nível em educação fundamental e seria de desejar que tivesse um caráter universitário ou post-universitário. Desta maneira se evitariam os equívocos do C.R.E.F.A.L., o Centro Regional de Educação Fundamental para a Ar.érica Latina, situado em Patzcuaro, no México.

Além das deficiências de técnica e programa do C.R.E.F.A.L., é inteiramente desarrazoado imaginar que, no México, se possam formar educadores para todos os países da América Latina. $O$ mais importante para o educador de base é a compreensão sociológica e ecológica de sua área de trabalho. As técnicas educacionais que aprende estão condicionadas, em sua aplicação, a essa visão dos problemas de base que só um contato direto com a região the pode proporcionar. Um centro de treinamento fixado num Estado brasileiro atende aos problemas dos demais Estados, apenas na medida em que todos participam de uma cultura e de uma sociedade comum. Atenderá melhor aos problemas de regiấo onde fôr localizado porque nesta há maior homogeneidade social e cultural. Mas faltará inteiramente a seus objetivos se tentar formar educadores para culturas e sociedades tão diversificadas como são as de tôda a América Latina. Não se pode desprender o conceito de educação fundamental da realidade humana em que vai trabalhar o educador com todo o seu condicionamento geográfico, social e econômico. A educação fundamental não é uma simples técnica, mas um convívio, uma demorada reflexão sôbre os problemas do povo rural sentidos na sua vida cotidiana.

É curioso lembrar que muito se falou, entre nós, na criação de um centro regional para a América Latina, isto é, um segundo C.R.E.F.A.L. que viesse quebrar, para os americanos de língua portuguêsa, o absurdo monopólio do México. Paulo Carneiro, quando na Presidência da U.N.E.S.C.O., não poupou esforços para dotar o Brasil de um centro de educação de base à altura de suas necessidades. A U.N.E.S.C.O. chegou a enviar ao Brasil por volta de 1952, um técnico em educação. Nessa época, a experiência de Pinhal já estava em funcionamento e devia merecer, lògicamente, a primeira visita. O técnico, entretanto, dispunha de pouco tempo, uma semana e, num grande esforço para conhecer o Brasil, fêz uma excursão a Teresópolis, em dia chuvoso que não the permitiu apreender sequer a beleza da paisagem serrana, mas que o encheu de otimismo quanto às possibilidades de instalação de outro C.R.E. F.A.L., nas proximidades do Dedo de Deus. Voltando, porém, à Europa visitou provàvelmente recantos mais adequados e acabou por concluir, em relatório, que o Brasil não apresentava condições para semelhante empreendimento. (sic). O assunto foi encerrado para desespêro dos nossos ufanistas, convencidos, não menos errôneamente que seus congêneres mexicanos, que o Brasil era o local por excelência para o centro de educação fundamental, quando êsse centro, por sua vocação própria, tem de ser regional, no sentido estritamente sociológico da palavra, e năo no amplo e geopolítico que the emprestaram os técnicos da U.N.E.S.C.O. 
A criação de centros regionais ou estaduais, no Brasil, estaria dentro do espírito da federação, amiúde esquecido pelos burocratas de formação totalitária que se infiltraram na administração pública brasileira e orientam, entre outras coisas, nossa política educacional. Determinaria uma sadia emulação entre os Estados, dando azo a uma ampla troca de experiências, muito mais fecunda que a criação monolítica de um único centro nacional. Essa disseminação dos centros de treinamento, orientados e auxiliados pelo Ministério da Educação, ajudaria o Estado a tomar consciência de suas responsabilidades no terreno educacional e também da extensão e complexidade do problema, tirando seus técnicos da cláusula acadêmica em que vivem, partejando teorias e esquemas, eternos ausentes no drama educacional brasileiro.

Ao mesmo tempo que caminhava para a descentralização, a C.N.E.R. visava o estímulo da iniciativa particular, sem a qual não se resolverá no Brasil nenhum problema de educação, a começar pelo analfabetismo. Será vã presunção imaginar que tôda a burocracia federal, estadual e municipal seja suficiente a arcar com um décimo das deficiências do país em matéria educacional. Mas para mover essa iniciativa particular é preciso inspirar-1he confiança pela seriedade de propósitos e pela renúncia à centralização e à asfixia. A colaboração com a iniciativa particular que, em muitas áreas do Brasil, iá se acha pronta até a financiar trabalhos educacionais, diminuiria, para o Estado, o custo do trabalho, permitindo transferir maior soma de recursos para regiões mais necessitadas, e despertaria vocações pedagógicas que, de outra forma, nunca terão oportunidade de manifestar-se.

Não há dúviđa, também, que a produção de materiais educativos, tanto os impressos, quanto os audio-visuais, foi inteiramente descurada. A publicação de revistas em papel "couché" não supre de forma alguma a necessidade de manuais, livros e folhetos, em papel barato, até mimeografados, que satisfaçam a grande fome de matéria escrita que vai pelo interior. As noçóes ministradas nos cursos, dessa forma renovadas, alcançariam difusão cada vez maior. Além disso, a divulgação educativa é, em si mesma, um campo de ação específico da C.N.E.R. inteiramente abandonado sem que outro organismo esteja em condições de substituí-la.

A dispersão das missões rurais, cujo fito inicial era o de constituir núcleos de demonstração e, principalmente, o divórcio entre missão e centro social, que deviam funcionar entrosados, parece-nos outra falha. O mapa do, Brasil é uma grande tentação para os administradores. Semeá-lo de alfinetes, pontos brancos ou pretos, círculos ou bolotas coloridas proporciona-lhes deliciosa sensação de poder. Essa sensação é enganosa. No Brasil, como em tantas outras regiōes do mundo, em cujo âmbito há vastas zonas subdesenvolvidas, onde escassos recursos ainda se acham concentrados em meia dúzia de centros urbanos, impóe-se a política da mancha de azeite, imperativo de economia e prudência.

A distribuição das missões em zonas econômł̇amente estratégicas traria duas vantagens: permitiria a colaboração com outros serviços, funcionando a C.N.E.R. numa dupla missão pedagógica junto às populações e junto às outras entidades, difundindo seus processos educacionais e ampliando extraordinàriamente seu círculo de influência. A colaboração com o S.E.S.P., com 
a Comínsão do Vale do São Francisco, com os demais serviços agrícolas, sanitários e educacionais, faria que êstes recebessem o apoio da liderança local cuja importância muitos ainda não perceberam. A outra vantagem seria a diversificação do tipo de missão, que revelaria tôda a sua flexibilidade, seu poder de adaptação às variaçôes regionais.

A C̈.N.E.R., como todo amplo movimento educacional, tinha sua dinâmica própria e sofreu inegável paralisia. Seu crescimento não corresponde ao que podia dar nem ao que o país espera que ela dê. $O$ simples aumento das verbas orçamentárias, numa situação inflacionária, não exprime crescimento orgânico. O contrário é que seria de desejar. Quando muito, as verbas deviam crescer pari passu com as realizações programadas. E inacreditável que até hoje não se tenha feito uma avaliação precisa dessas realizações. Nem mesmo foi criado o instrumento de avaliação. As missōes são instaladas, trabalham anos e anos, são transferidas ou extintas sem se saber ao certo por que motivo, e qual o rendimento de sua atividade. Não se trata, evidentemente, de avaliação estatística, aqui inteiramente descabida, mas de um balanço de experiências que permita planejamentos mais seguros.

Não culpemos, todavia, os técnicos por essas falhas. Na verdade, a C.N.E.R. tem sobrevivido heròicamente à custa do entusiasmo e idealismo do grupo de moços que the são fiéis desde o comêço. Poucos serviços têm enfrentado tão severos contratempos. Em 1952, a Campanha de Educação de Adultos, dentro do próprio Ministério, procurava sabotar os seus trabalhos, julgando-a uma excrescência. Depois, outros órgãos do Ministério melhor aquinhoados envesgavam para ela os olhos como para a Borralheira da fábula. A direção vacilante e incoerente do Departamento Nacional de Educação lançava-a diàriamente no snake pit das intrigas de gabinete. Ao mesmo tempo, o Ministério da Agricultura dirigia um pedido ao D.A.S.P. para que cortasse as verbas por se tratar de educação rural e, porisso (sic), estar invadindo a órbita do Ministério. Esse ataque provocou um esclarecimento léxico do D.A.S.P. o qual, em Exposição de Motivos (*), ponderou que "rural" era adjetivo e "educação", substantivo. Daí, maiores dificuldades ao trabalho pois o Ministério passou ostensivamente a combatê-la forçando a retração dos serviços agrícolas federais que com ela colaboravam em diversas regiōes do país. Tão flagrante se tornou essa disputa insensata que culminou num duelo epistolar entre os Ministros das duas pastas. $\mathrm{Na}$ realidade, por trás dessa discordância gramatical, havia o desejo de monopolizar a verba em dólares do acôrdo a ser firmado entre o Govêrno brasileiro e o Ponto IV para desenvolvimento da educação rural. Esperava o Ministério da Agricultura, com essa milagrosa infusão de moeda americana restaurar o seu combalido orçamento e tudo fêz para tomar assento na comissão encarregada de gerir as somas que seriam postas à disposição do Govêrno brasileiro. Diante dessa guerra intestina entre os beneficiários que nem conseguiam apurar o que entendiam por educação rural o Ponto IV adiou o programa e os dólares não vieram.

(*) Exposição de Motivos, n. ${ }^{\circ} 29$, de 6 de janeiro de 1953, reproduzida na seção Notas do presente número. (N.R.). 
Tentou, então, o Ministério da Agricultura demolir a Campanha por outros meios, denunciando ao Presidente da República os elevados salários que a C.N.E.R. estava pagando a seus agrônomos, roubando-os (sic) aos quadros do Ministério. O que ocorria, de fato, era que os agrônomos da Campanha trabalhavamem regime de tempo integral, no interior, vindo à Capital, apenas, em períodos de férias. Além disso, eram recrutados diretamente das Escolas de Agronomia ou dos serviços estaduais em acôrdo com a Campanha, ou ainda da A.C.A.R., serviço criado pela Rockfeller, em Minas Gerais, para dar assistência ao crédito agrícola supervisionado. Os salários correspondiam inteiramente ao tempo de serviço e às responsabilidades dêsses técnicos, muito diversos das atribuições burocráticas das repartições ministeriais. Malogrou igualmente essa tentativa que só serviu para desmoralizar um pouco mais o Ministério nas Escolas de Agronomia.

Tudo isso representava um desestímulo aos técnicos da Campanha que, constantemente, se viam forçados a abandonar tarefas de importância, no campo, para acudir em defesa do seu patrimônio ameaçado. Repetidas vêzes, pediu-se ao Ministro da Educação que, atendendo à importância do serviço, sustasse, de uma vez por tôdas, os ataques que a C.N.E.R. vinha sofrendo dentro e fora do Ministério. Em 1952, o Chefe de Gabinete do Ministro da Educação, num seminário de educação fundamental levado a efeito em Paris, anunciou que o Ministério pretendia transformar a Campanha de Educação de Adultos e a Campanha de Educação Rural num serviço único que seria - Departamento Nacional de Educação Fundamental, englobando tôdas essas atividades. Parece que o projeto chegou a ser encaminhado ao Presidente da República, mas não teve conseqüências.

Os ministros que se sucederam na pasta da Educação nunca deram à C.N.E.R. a importância merecida. Cercearam-lhe as verbas, retardaram os pagamentos ao seu pessoal, tiraram-lhe tôda autonomia administrativa. Sua direção oscilou entre o Departamento Nacional de Educação e o Gabinete do Ministro. Depois de ter instalações próprias, recambiaram-na, por economia (!) ao edifício do Ministério, onde teve de se subordinar ao horário comum de expediente, passando seus funcionários a trabalhar no horário normal das outras repartições, inteiramente inadequado ao seu tipo de atividade. $\mathrm{Em}$ 1955, as missões passaram seis meses no campo sem a menor supervisão e sem receber seus vencimentos. Enviavam seus relatórios para o Rio e recebiam a resposta a suas perguntas... por carta. Os executores de acôrdo ficaram a metade do ano aguardando suas verbas, sem poder dar início aos trabalhos planejados, ouvindo as queixas e assistindo à deserção do seu pessoal. No ano corrente, repete-se a situação. Trabalha-se, até agora, com os saldos do ano findo.

Não há, portanto, que culpar os técnicos, os jovens médicos, agrônomos, assistentes sociais, enfermeiras e educadores que tudo fizeram para que a Campanha sobrevivesse e que, buscando-a, só tiveram um nobre ideal de servir. Seu trabalho teve, entre muitas derrotas e retrocessos, um resultado. Mostrou as grandes reservas humanas do país. Revelou a fecundidade de um encontro 
entre a elite técnica e a massa trabalhadora no campo educacional. Apontou aos legisladores o caminho natural para execução de um plano nacional de reforma agrária, onde a distribuição da terra terá de ser necessàriamente acompanhada de uma assistência agrícola, educacional e médico-sanitária aos novos proprietários. Provou a possibilidade de transfundir numa estrutura administrativa corrompida pelo compadrio, solapada pela crise de autoridade e diminuída pelo baixo estalão dos seus dirigentes, o idealismo e a capacidade criadora da gente moça. Esquecidos dos educadores do asfalto, sem recursos materiais, sem equipamento, às vêzes sem a paga a que têm direito, continuam, pelas estradas do interior, conversando, ensinando, convencendo. Numa era de infidelidades, mantêm-se fiéis à sua vocação de educadores e seu exemplo é uma simples e luminosa lição de fraternidade humana. 